\title{
A Chemo-Enzymatic Route to Enantiomerically Pure Cyclic Tertiary Amines
}

Colin J. Dunsmore, Reuben Carr, Toni Fleming, and Nicholas J. Turner, ${ }^{\dagger}$

School of Chemistry, University of Edinburgh, King's Buildings, West Mains Road, Edinburgh, EH9 3JJ, UK

\section{SUPPORTING INFORMATION}

\section{General methods}

${ }^{1} \mathrm{H}$ and ${ }^{13} \mathrm{C}$ spectra were recorded on a Brüker AC250 instrument. Chemical shifts $(\delta)$ are reported in parts per million (ppm) and coupling constants $(J)$ in $\mathrm{Hz}$. Residual protic solvent, $\mathrm{CHCl}_{3}\left(\delta_{\mathrm{H}} 7.26, \mathrm{~s}\right)$ was used as the internal standard in ${ }^{1} \mathrm{H}$ NMR spectra, and ${ }^{13} \mathrm{C}$ NMR shifts were referenced using $\mathrm{CDCl}_{3}\left(\delta_{\mathrm{C}} 77.0, \mathrm{t}\right)$ with broad band decoupling. Electrospray (ES) nominal mass spectra were recorded using a Micromass Platform II mass spectrometer $(\mathrm{CV}=35)$. Microwave reactions were carried out in a CEM Discover Microwave Synthesiser. The reaction conditions were monitored using a pressure probe which was inserted through the septum of the reaction tube and black body irradiation measured to monitor the temperature of the sample. Normal phase high performance liquid chromatography (HPLC) was performed on a Waters 600 controller/pump utilising a Waters 486 tunable absorbance detector and equipped with a Chiracel-ODH column with dimensions $25 \times 0.46 \mathrm{~cm}$. Samples were injected via a $20 \mu 1$ loop with a flow rate of $1 \mathrm{ml} / \mathrm{min}$ and eluted with an isocratic system of hexane/isopropanol (99:1). A wavelength of 254 $\mathrm{nm}$ was used for sample detection. Capillary electrophoresis (CE) was performed on an Agilent CE system G1601A with a capillary diameter of $50 \mu \mathrm{m}$ and length $64.5 \mathrm{~cm}$ (effective length $56 \mathrm{~cm}$ ) using a $30 \mathrm{kV}$ potential and column temperature of $20^{\circ} \mathrm{C}$. Samples were injected at a pressure of $50 \mathrm{mbar} / \mathrm{sec}$ and eluted with $0.1 \mathrm{M}$ potassium phosphate buffer $(\mathrm{pH} \mathrm{3})$ containing $75 \mathrm{mM} \mathrm{HP}-\beta$-cyclodextrin and $75 \mathrm{mM} 18$ crown-6. A wavelength of $195 \mathrm{~nm}$ was used for sample detection. Optical rotations were performed on an AA1000 polarimeter from Optical Activity Ltd. (measurements made at the sodium D-line). Concentrations are given in g/100 ml. Flash chromatography was carried out using silica gel $60 \mathrm{H}$ (Merck 9385, 0.04-0.063 mm, 230-400 mesh). Anhydrous solvents were purchased from Aldrich or Baker and used as received. Other solvents and reagents were standard laboratory grade and used without further purification. Commercially available substrates were purchased and used as received.

Preparation of 2-phenylpyrrolidine (2) via 2-step process from pyrrolidin-2-one<smiles>CC1(C)CCC(c2ccccc2)=N1</smiles> 
Pyrrolidin-2-one $(10.0 \mathrm{~g}, 117 \mathrm{mmol})$ was dissolved in ether $(150 \mathrm{ml})$ and triethylamine $(17.3 \mathrm{ml}, 123$ mmol) added. The mixture was cooled to $0{ }^{\circ} \mathrm{C}$ and chlorotrimethylsilane $(15.6 \mathrm{ml}, 123 \mathrm{mmol})$ slowly added. The mixture was then refluxed for $30 \mathrm{~min}$, cooled, and filtered. Phenylmagnesium bromide (39.2 $\mathrm{ml}, 117 \mathrm{mmol}$ ) was added to the filtrate under argon and the resulting mixture heated under reflux for 3 hours. After cooling to room temperature, the reaction was quenched with $1 \mathrm{M} \mathrm{HCl}(60 \mathrm{ml})$ and the layers separated. The aqueous phase was basified to $\mathrm{pH} 10$ with $2 \mathrm{M} \mathrm{NaOH}$ solution and extracted with EtOAc (3 $x 50 \mathrm{ml})$. The total organic phase was washed with brine $(30 \mathrm{ml})$, dried $\left(\mathrm{Na}_{2} \mathrm{SO}_{4}\right)$, and concentrated in vacuo to give an orange liquid $(8.0 \mathrm{~g})$. Purification by flash chromatography on silica gel using hexane/EtOAc (1:1) as eluent afforded 2-phenylpyrroline (5.1 g, $30 \%): \delta_{\mathrm{H}}\left(250 \mathrm{MHz}, \mathrm{CDCl}_{3}\right) 2.02(2 \mathrm{H}, \mathrm{m}$, $\left.\mathrm{CH}_{2}\right), 2.93\left(2 \mathrm{H}, \mathrm{m}, \mathrm{CH}_{2}\right), 4.06\left(2 \mathrm{H}, \mathrm{m}, \mathrm{CH}_{2}\right), 7.40(3 \mathrm{H}, \mathrm{m}, \mathrm{Ar}-\mathrm{H}), 7.83(2 \mathrm{H}, \mathrm{m}, \mathrm{Ar}-\mathrm{H})$; MS ES (+ve) found $\mathrm{m} / \mathrm{z} 146.0\left(\mathrm{MH}^{+}, 100 \%\right)$.

2-phenylpyrroline $(1.00 \mathrm{~g}, 6.89 \mathrm{mmol})$ was dissolved in $\mathrm{MeOH} / \mathrm{H}_{2} \mathrm{O}(4: 1,25 \mathrm{ml})$ and sodium borohydride $(0.29 \mathrm{~g}, 7.71 \mathrm{mmol})$ added. The mixture was then stirred at room temperature overnight. The mixture was acidified to $\mathrm{pH} \mathrm{1-3}$ with $2 \mathrm{M} \mathrm{HCl}$ and left for $30 \mathrm{~min}$. $2 \mathrm{M} \mathrm{NaOH}$ solution was then added until the $\mathrm{pH}$ was 13-14 and the product extracted with DCM $(3 \times 25 \mathrm{ml})$. The total organic phase was dried $\left(\mathrm{Na}_{2} \mathrm{SO}_{4}\right)$ and concentrated in vacuo to give a colorless liquid which was purified by Kugelrohr distillation to yield 2phenylpyrrolidine (2) (0.98 g, $97 \%$ ): $\delta_{\mathrm{H}}\left(250 \mathrm{MHz}, \mathrm{CDCl}_{3}\right) 1.78\left(3 \mathrm{H}, \mathrm{m}, \mathrm{CH}_{2}+\mathrm{CH}^{\mathrm{A}} \mathrm{H}^{\mathrm{B}}\right), 2.09(1 \mathrm{H}, \mathrm{s}, \mathrm{NH})$, $2.19\left(1 \mathrm{H}, \mathrm{m}, \mathrm{CH}^{\mathrm{A}} H^{\mathrm{B}}\right), 3.01\left(1 \mathrm{H}, \mathrm{ddd}, J 10.2,8.1,6.7, \mathrm{NHCH}^{\mathrm{A}} \mathrm{H}^{\mathrm{B}}\right), 3.21(1 \mathrm{H}, \mathrm{ddd}, J 10.2,7.6,5.4$, $\left.\mathrm{NHCH}^{\mathrm{A}} H^{\mathrm{B}}\right), 4.12(1 \mathrm{H}$, dd. J 7.6, 7.6, $\mathrm{NHCH}), 7.29(5 \mathrm{H}, \mathrm{m}, \mathrm{Ar}-H)$; MS ES (+ve) found $m / z 148.0\left(\mathrm{MH}^{+}\right.$, $100 \%)$.

\section{General procedure for the methylation of secondary amines}

The secondary amine $(0.50 \mathrm{~g})$ was suspended in water $(4 \mathrm{ml})$ in a microwave test tube and formic acid (1.1 eq) and formaldehyde ( $1.1 \mathrm{eq}, 37 \%$ solution in $\mathrm{H}_{2} \mathrm{O}$ ) added. The tube was sealed with a septum and heated using microwave radiation at $150{ }^{\circ} \mathrm{C}(120 \mathrm{~W})$ for $5 \mathrm{~min}$. Once cool, the mixture was basified to $\mathrm{pH} 14$ with $2 \mathrm{M} \mathrm{NaOH}$ solution and extracted with $\mathrm{DCM}(3 \times 10 \mathrm{ml})$. The total organic phase was dried $\left(\mathrm{Na}_{2} \mathrm{SO}_{4}\right)$ and concentrated in vacuo to give the crude tertiary amine product, which was purified by Kugelrohr distillation.

\section{$N$-Methyl-2-phenylpyrrolidine (3) ${ }^{1}$}

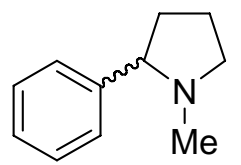

Colorless liquid, (0.32 g, $58 \%$ ): $\delta_{\mathrm{H}}\left(250 \mathrm{MHz}, \mathrm{CDCl}_{3}\right) 1.98\left(4 \mathrm{H}, \mathrm{m}, 2 \times \mathrm{CH}_{2}\right), 2.18\left(3 \mathrm{H}, \mathrm{s}, \mathrm{NCH}_{3}\right), 2.29$ $\left(1 \mathrm{H}, \mathrm{m}, \mathrm{NCH}^{\mathrm{A}} \mathrm{H}^{\mathrm{B}}\right), 3.04(1 \mathrm{H}, \mathrm{m}, \mathrm{NCH}), 3.26\left(1 \mathrm{H}, \mathrm{m}, \mathrm{NCH}^{\mathrm{A}} H^{\mathrm{B}}\right), 7.29(5 \mathrm{H}, \mathrm{m}, \mathrm{Ar}-H)$; MS ES (+ve) found $\mathrm{m} / \mathrm{z} 162.0\left(\mathrm{MH}^{+}, 100 \%\right)$. 


\section{$N$-Methyl-2-phenylpiperidine (5) ${ }^{1}$}<smiles>CN1CCCC[C@H]1c1ccccc1</smiles>

Colorless liquid, $(0.22 \mathrm{~g}, 41 \%): \delta_{\mathrm{H}}\left(250 \mathrm{MHz}, \mathrm{CDCl}_{3}\right) 1.35\left(1 \mathrm{H}, \mathrm{m}, \mathrm{CH}^{\mathrm{A}} \mathrm{H}^{\mathrm{B}}\right), 1.69\left(5 \mathrm{H}, \mathrm{m}, 2 \times \mathrm{CH}_{2}+\right.$ $\left.\mathrm{CH}^{\mathrm{A}} H^{\mathrm{B}}\right), 1.99\left(3 \mathrm{H}, \mathrm{s}, \mathrm{NCH}_{3}\right), 2.11\left(1 \mathrm{H}, \mathrm{dd}, J 10.7,3.1, \mathrm{NCH}^{\mathrm{A}} \mathrm{H}^{\mathrm{B}}\right), 2.75(1 \mathrm{H}, \mathrm{m}, \mathrm{NCH}), 3.03(1 \mathrm{H}, \mathrm{m}$, $\left.\mathrm{NCH}^{\mathrm{A}} H^{\mathrm{B}}\right), 7.26(5 \mathrm{H}, \mathrm{m}, \mathrm{Ar}-H)$; MS ES (+ve) found $\mathrm{m} / \mathrm{z} 175.9\left(\mathrm{MH}^{+}, 100 \%\right)$.

\section{(S)-N-Methyl-2-methoxymethylpyrrolidine (8) ${ }^{2}$}<smiles>COC[C@@H]1CCCN1C</smiles>

Colorless liquid, $(0.06 \mathrm{~g}, 11 \%): \delta_{\mathrm{H}}\left(250 \mathrm{MHz}, \mathrm{CDCl}_{3}\right) 1.74\left(4 \mathrm{H}, \mathrm{m}, 2 \times \mathrm{CH}_{2}\right), 2.18\left(1 \mathrm{H}, \mathrm{m}, \mathrm{NCH} \mathrm{H}^{\mathrm{A}}\right)$, $2.34\left(1 \mathrm{H}, \mathrm{m}, \mathrm{NCH}^{\mathrm{A}} H^{\mathrm{B}}\right), 2.38\left(3 \mathrm{H}, \mathrm{s}, \mathrm{NCH}_{3}\right), 3.04(1 \mathrm{H}, \mathrm{m}, \mathrm{NCH}), 3.31\left(1 \mathrm{H}, \mathrm{dd}, J\right.$ 9.4, 5.5, $\left.\mathrm{MeOCH}^{\mathrm{A}} \mathrm{H}^{\mathrm{B}}\right)$, $3.34\left(3 \mathrm{H}, \mathrm{s}, \mathrm{CH}_{3} \mathrm{O}\right), 3.40\left(1 \mathrm{H}, \mathrm{dd}, J\right.$ 9.4, 5.1, $\left.\mathrm{MeOCH}^{\mathrm{A}} \mathrm{H}^{\mathrm{B}}\right) ; \delta_{\mathrm{C}}\left(63 \mathrm{MHz}, \mathrm{DEPT}, \mathrm{CDCl}_{3}\right) 22.7\left(\mathrm{CH}_{2}\right), 28.5$ $\left(\mathrm{CH}_{2}\right), 41.4\left(\mathrm{NCH}_{3}\right), 57.7\left(\mathrm{NCH}_{2}\right), 59.1\left(\mathrm{CH}_{3} \mathrm{O}\right), 64.8(\mathrm{NCH}), 75.7\left(\mathrm{MeOCH}_{2}\right)$; MS ES (+ve) found $\mathrm{m} / \mathrm{z}$ $129.9\left(\mathrm{MH}^{+}, 100 \%\right), 98.1\left(\mathrm{MH}^{+}-\mathrm{OMe}, 8\right)$.

\section{$N$-Methyl-2-methyl-1,2,3,4-tetrahydroisoquinoline (10) ${ }^{3}$}<smiles>CC1c2ccccc2CCN1C</smiles>

Colorless liquid, (0.93 g, $58 \%$ ) [based on $1.47 \mathrm{~g}$ of starting material]: $\delta_{\mathrm{H}}\left(250 \mathrm{MHz}, \mathrm{CDCl}_{3}\right) 1.40(3 \mathrm{H}, \mathrm{d}, J$ 6.5, $\left.\mathrm{CHCH}_{3}\right), 2.49\left(3 \mathrm{H}, \mathrm{s}, \mathrm{NCH}_{3}\right), 2.64\left(1 \mathrm{H}, \mathrm{m}, \mathrm{NCH}_{2} \mathrm{CH}^{\mathrm{A}} \mathrm{H}^{\mathrm{B}}\right), 2.86\left(2 \mathrm{H}, \mathrm{m}, \mathrm{NCH}^{\mathrm{A}} \mathrm{H}^{\mathrm{B}} \mathrm{CH}^{\mathrm{A}} H^{\mathrm{B}}\right), 3.05(1 \mathrm{H}$, $\left.\mathrm{m}, \mathrm{NCH}^{\mathrm{A}} \mathrm{H}^{\mathrm{B}} \mathrm{CH}_{2}\right), 3.62\left(1 \mathrm{H}, \mathrm{q}, J\right.$ 6.5, $\left.\mathrm{CHCH}_{3}\right), 7.12(4 \mathrm{H}, \mathrm{m}, \mathrm{Ar}-H)$; MS ES (+ve) found $\mathrm{m} / \mathrm{z} 161.9\left(\mathrm{MH}^{+}\right.$, $100 \%)$.

\section{Expression and purification of variant amine oxidase (MAO-N-5)}

BL21 star was transformed with the variant MAO-N-5 amine oxidase gene and plated onto LB $(70 \mu \mathrm{g} / \mathrm{ml}$ ampicillin) petri dishes. A single colony was added to $6 \times 300 \mathrm{ml} \mathrm{LB}$ media containing ampicillin and grown at $30^{\circ} \mathrm{C}$ for $24 \mathrm{~h}$. The cells were spun and the cell pellet stored at $-20^{\circ} \mathrm{C}$. Lysis of the cells was performed in $25 \mathrm{mM}$ Tris/ $\mathrm{HCl} \mathrm{pH} 7.8,10 \mathrm{mM}$ imidazole, $1 \mathrm{mM} \beta$-mercaptoethanol, $1 \mathrm{mM}$ PMSF and $300 \mathrm{mM} \mathrm{NaCl}$ and the lysate centrifuged. The cell-free extract from a $1 \mathrm{~g}$ pellet was loaded onto a $1 \mathrm{ml} \mathrm{Ni}$ NTA column. Column wash (5 column volumes); $25 \mathrm{mM}$ Tris/HCl $\mathrm{pH} 7.8,60 \mathrm{mM}$ imidazole, $1 \mathrm{mM} \beta-$ 
mercaptoethanol, $1 \mathrm{mM}$ PMSF and $300 \mathrm{mM} \mathrm{NaCl}$. Protein elution (the amine oxidase elutes in $\sim 2^{\text {nd }}-7^{\text {th }} 1 \mathrm{ml}$ fractions); $25 \mathrm{mM}$ Tris/HCl pH7.8, 200mM imidazole, $1 \mathrm{mM} \beta$-mercaptoethanol, $1 \mathrm{mM}$ PMSF and 300mM $\mathrm{NaCl}$. The protein was desalted in $25 \mathrm{mM}$ Tris/ $\mathrm{HCl} \mathrm{pH} 7.8,1 \mathrm{mM}$ DTT, $1 \mathrm{mM}$ PMSF and $300 \mathrm{mM} \mathrm{NaCl}$ using a Pharmacia PD10 column. Samples were stored frozen at $-80^{\circ} \mathrm{C}$ and thawed prior to use.

\section{General procedure for determination of the relative activity of amine substrates}

The following assay solution was prepared; $1 \mathrm{M}$ 4-aminoantipyrine (37.5 $\mu \mathrm{l}), 2 \%$ (w/v) 2,4,6-tribromo-3hydroxybenzoic acid in DMSO $(500 \mu \mathrm{l}), 10 \mathrm{mM}$ (after dilution) of amine $(54 \mu \mathrm{l}), 1 \mathrm{M}$ potassium phosphate buffer $\mathrm{pH} 7.6(5 \mathrm{ml})$ and finally water to give a final volume of $50 \mathrm{ml}$.

$5 \mu \mathrm{l}$ of $1 \mathrm{mg} / \mathrm{ml}$ HRP (Horseradish peroxidase, Sigma P-6782) was added to $10 \mu \mathrm{l}$ of the purified MAO-N protein sample in a U-shaped 96-well microtitre plate. To this was added $185 \mu$ of the assay solution giving a final volume of $200 \mu \mathrm{l}$. The colorimetric product formation was monitored by at $\lambda=510 \mathrm{~nm}$ with a plate reader (Molecular Devices, VersaMax tunable microplate reader) at $30^{\circ} \mathrm{C}\left(\varepsilon=29400 \mathrm{M}^{-1} \mathrm{~cm}^{-1}\right)^{178}$. The activity of MAO-N towards the amine was calculated from the rate of change of absorbance. Relative activities were determined by dividing the rate measured for the specific amine by the rate for the reference substrate $\alpha$-methylbenzylamine $\mathbf{1}$.

\section{General procedure for small-scale deracemization or stereoinversion of tertiary amines}

Whole cells $(1.0 \mathrm{~g})$ expressing the MAO-N-5 variant were thawed on ice and then suspended in $0.1 \mathrm{M}$ potassium phosphate buffer $\mathrm{pH} 7(10 \mathrm{ml})$. To this suspension was added the tertiary amine substrate $(10$ $\mathrm{mM})$ followed by ammonia borane $(100 \mathrm{mM})$. The mixture was left shaking in an incubator $\left(37^{\circ} \mathrm{C}, 200\right.$ $\mathrm{rpm})$ and samples $(200 \mu \mathrm{l})$ taken periodically for analysis. Samples were placed on a hot-plate set to 100 ${ }^{\circ} \mathrm{C}$ for $5 \mathrm{~min}$ to denature the enzyme, and then spun at maximum speed $(13,000 \mathrm{rpm})$ on a microcentrifuge. The supernatant was decanted and analysed directly by $\mathrm{CE}$, or basified to $\mathrm{pH} 13$ with $2 \mathrm{M} \mathrm{NaOH}$ solution and extracted into TBME for analysis by chiral HPLC.

\section{Deracemization of $N$-methyl-2-phenylpyrrolidine (3)}

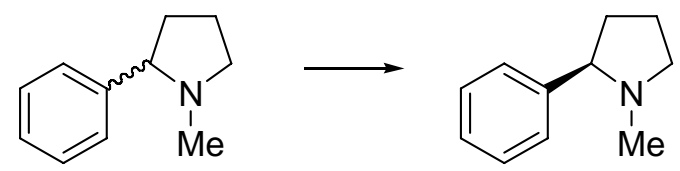

Reaction monitored by CE (see General methods section for conditions): $t_{\mathrm{R}} 33.0 \mathrm{~min}, 99 \%$ ee after 24 hours $\left[\mathrm{t}_{\mathrm{R}}(R)-3=33.0 \mathrm{~min}, \mathrm{t}_{\mathrm{R}}(S)-3=34.0 \mathrm{~min}\right]$.

\section{Stereoinversion of $S$-nicotine (4)}




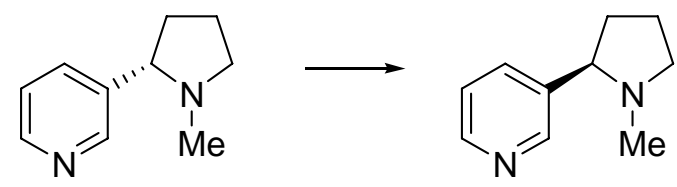

Reaction monitored by chiral HPLC (see General methods section for conditions): $t_{R} 11.9$ min, $99 \%$ ee after 24 hours $\left[\mathrm{t}_{\mathrm{R}}(S)-\mathbf{4}=10.1 \mathrm{~min}, \mathrm{t}_{\mathrm{R}}(R)-\mathbf{4}=11.9 \mathrm{~min}\right]$.

\section{Procedure for preparative deracemization of $N$-methyl-2-phenylpyrrolidine (3)}

Whole cells $(10.0 \mathrm{~g})$ expressing the MAO-N-5 variant were thawed on ice and then suspended in $0.1 \mathrm{M}$ potassium phosphate buffer $\mathrm{pH} 7(100 \mathrm{ml})$. To this suspension was added $N$-methyl-2-phenylpyrrolidine 3 $(0.40 \mathrm{~g}, 25 \mathrm{mM})$ followed by ammonia borane $(0.39 \mathrm{~g}, 125 \mathrm{mM})$. The mixture was left shaking in an incubator $\left(37^{\circ} \mathrm{C}, 200 \mathrm{rpm}\right)$ and samples $(200 \mu \mathrm{l})$ taken periodically for analysis by CE. When the reaction had reached completion, the mixture was acidified to $\mathrm{pH} 1-3$ with $2 \mathrm{M} \mathrm{HCl}$ and centrifuged at $4000 \mathrm{rpm}$ for $10 \mathrm{~min}$. The supernatant was decanted and centrifuged at $4000 \mathrm{rpm}$ for a further $10 \mathrm{~min}$. The supernatant was decanted, basified to $\mathrm{pH} 13-14$ with $2 \mathrm{M} \mathrm{NaOH}$ solution, and continuously extracted with TBME overnight. The TBME phase was concentrated in vacuo to afford the product as a colorless liquid $(0.30 \mathrm{~g}$, $75 \%):[\alpha]^{\mathrm{RT}}=+162^{\circ}\left(c 1.0, \mathrm{CHCl}_{3}, 99 \%\right.$ ee) $\left[\mathrm{lit}^{4}{ }^{4}[\alpha]^{\mathrm{RT}}{ }_{\mathrm{D}}=+156.5^{\circ}\right.$ (neat)]; ${ }^{1} \mathrm{H}$ NMR identical to that described above for $N$-methyl-2-phenylpyrrolidine 3.

\section{Preparation of 3-(3'-pyridyl)-1-methylpyrroldin-2-one e $^{5}$}<smiles>CN1CCC(C(=O)c2cccnc2)C1=O</smiles>

$N$-Methylpyrrolidin-2-one (5.00 g, $0.05 \mathrm{~mol})$ in anhydrous THF (5 ml) was added dropwise to a suspension of sodium hydride (60\% in oil, $6.05 \mathrm{~g}, 0.15 \mathrm{~mol})$ in anhydrous THF $(40 \mathrm{ml})$ and the resulting mixture stirred for $15 \mathrm{~min}$ at room temperature. A solution of ethyl nicotinate $(13.80 \mathrm{ml}, 0.10 \mathrm{~mol})$ in anhydrous THF ( $5 \mathrm{ml}$ ) was then added dropwise and the mixture heated under reflux for 24 hours. After allowing to cool, the mixture was poured into ice-cold $4 \mathrm{M} \mathrm{HCl}(50 \mathrm{ml})$. Solid $\mathrm{NaOH}$ was used to carefully adjust the $\mathrm{pH}$ of the solution to 4 , and the aqueous was then extracted with DCM $(6 \times 15 \mathrm{ml})$. The total organic phase was concentrated in vacuo and the residue taken-up in DCM $(50 \mathrm{ml})$, dried $\left(\mathrm{MgSO}_{4}\right)$, and concentrated in vacuo to give a brown oil (10.0 g). Purification by flash chromatography on silica gel using EtOAc/MeOH (9:1) as eluent gave a yellow oil (5.30 g, $51 \%): \delta_{\mathrm{H}}\left(250 \mathrm{MHz}, \mathrm{CDCl}_{3}\right) 2.19\left(1 \mathrm{H}, \mathrm{m}, \mathrm{CH}^{\mathrm{A}} \mathrm{H}^{\mathrm{B}}\right), 2.63(1 \mathrm{H}, \mathrm{m}$, $\left.\mathrm{CH}^{\mathrm{A}} H^{\mathrm{B}}\right), 2.79\left(3 \mathrm{H}, \mathrm{s}, \mathrm{NCH}_{3}\right), 3.44\left(2 \mathrm{H}, \mathrm{m}, \mathrm{CH}_{2}\right), 4.39$ (1H, dd, J 9.2, 5.3, COCHCO), 7.34 (1H, ddd, J 8.0, 4.8, 0.5, Ar- $H), 8.36(1 \mathrm{H}, \mathrm{dt}, J$ 8.0, 1.9, Ar-H), $8.72(1 \mathrm{H}, \mathrm{dd}, J$ 4.8, 1.6, Ar- $H), 9.24(1 \mathrm{H}, \mathrm{d}, J 1.9, \mathrm{Ar}-H)$; MS ES (+ve) found $m / z 226.9\left(\mathrm{MNa}^{+}, 100 \%\right), 204.9\left(\mathrm{MH}^{+}, 72\right)$. 
Preparation of 4-(methylamino)-1-(3'-pyridyl)-1-butanone dihydrochloride (11) ${ }^{5}$<smiles>CNCCCC(=O)c1cccnc1</smiles>

3-(3'-pyridyl)-1-methylpyrroldin-2-one (5.30 g, $25.95 \mathrm{mmol})$ was dissolved in $5 \mathrm{M} \mathrm{HCl}$ and heated under reflux for 72 hours. The solution was allowed to cool and concentrated in vacuo and the residue taken-up in water $(100 \mathrm{ml})$. The mixture was filtered and the filtrate concentrated in vacuo to give a brown residue that was purified by recrystallization from EtOH/ $\mathrm{H}_{2} \mathrm{O}$ to afford a pale brown solid $(3.15 \mathrm{~g}, 48 \%)$ : $\delta_{\mathrm{H}}(250$ $\left.\mathrm{MHz}, \mathrm{D}_{2} \mathrm{O}\right) 1.94\left(2 \mathrm{H}, \mathrm{m}, \mathrm{CH}_{2}\right), 2.54\left(3 \mathrm{H}, \mathrm{s}, \mathrm{NCH}_{3}\right), 2.95\left(2 \mathrm{H}, \mathrm{t}, J\right.$ 7.8, $\left.\mathrm{CH}_{2}\right), 3.17\left(2 \mathrm{H}, \mathrm{t}, J\right.$ 6.8, $\left.\mathrm{CH}_{2}\right), 8.04$ $(1 \mathrm{H}, \mathrm{dd}, J$ 8.2, 6.0, Ar-H), 8.79 (1H, br-d, J 6.0, Ar-H), $8.90(1 \mathrm{H}, \mathrm{dt}, J$ 8.2, 1.7), $9.13(1 \mathrm{H}, \mathrm{d}, J$ 1.7, Ar-H); MS ES (+ve) found m/z $178.8\left(\mathrm{MH}^{+}-2 \mathrm{HCl}, 53 \%\right), 160.8(89), 147.8$ (100).

Preparation of $t$-Boc protected pyrrolidin-2-one (15) ${ }^{6}$<smiles>CC(C)(C)OC(=O)N1CCCC1=O</smiles>

To a stirred solution of pyrrolidin-2-one $(1.80 \mathrm{ml}, 23.53 \mathrm{mmol})$ in anhydrous THF $(50 \mathrm{ml})$ at $-78{ }^{\circ} \mathrm{C}$ was added $n$-butyllithium $(1.6 \mathrm{M}, 14.69 \mathrm{ml}, 23.53 \mathrm{mmol})$ dropwise, maintaining the temperature below $-70{ }^{\circ} \mathrm{C}$. The mixture was allowed to stir for 1 hour before a solution of di-tert-butyldicarbonate $(5.13 \mathrm{~g}, 23.53$ mmol) in anhydrous THF $(10 \mathrm{ml})$ was slowly added over $30 \mathrm{~min}$. The reaction was stirred for a further 2 hours and then allowed to warm to room temperature. Saturated $\mathrm{NH}_{4} \mathrm{Cl}$ solution $(25 \mathrm{ml})$ was added together with water $(12 \mathrm{ml})$ and the organic layer separated. The aqueous phase was extracted with diethyl ether $(3 \times 25 \mathrm{ml})$ and the total organic phase washed with brine $(50 \mathrm{ml})$, dried $\left(\mathrm{MgSO}_{4}\right)$, and concentrated in vacuo to give a yellow oil (4.44 g). Purification by flash chromatography on silica gel using hexane/EtOAc (1:4) as eluent afforded a pale yellow oil (2.69 g, $62 \%): \delta_{\mathrm{H}}\left(250 \mathrm{MHz}, \mathrm{CDCl}_{3}\right) 1.49(9 \mathrm{H}, \mathrm{s}$, $\left.\mathrm{C}\left(\mathrm{CH}_{3}\right)_{3}\right), 1.97\left(2 \mathrm{H}, \mathrm{m}, \mathrm{CH}_{2}\right), 2.48\left(2 \mathrm{H}, \mathrm{m}, \mathrm{CH}_{2}\right), 3.72\left(2 \mathrm{H}, \mathrm{m}, \mathrm{CH}_{2}\right)$; MS ES (+ve) found $\mathrm{m} / \mathrm{z} 186.2\left(\mathrm{MH}^{+}\right.$, $18 \%), 208.1\left(\mathrm{MNa}^{+}, 100\right)$.

\section{Preparation of (5-oxo-5-phenyl-butyl)-carbamic acid tert-butyl ester (16) ${ }^{6}$}<smiles>CC(C)(C)OC(=O)NCCCC(=O)c1ccccc1</smiles> 
To a stirred solution of $t$-Boc protected pyrrolidin-2-one 15 (2.60 g, $14.04 \mathrm{mmol})$ in anhydrous THF (55 $\mathrm{ml})$ at $-78^{\circ} \mathrm{C}$ was added phenylmagnesium bromide $(1.0 \mathrm{M}, 16.80 \mathrm{ml}, 16.84 \mathrm{mmol})$ dropwise over 1 hour, maintaining the temperature below $-70^{\circ} \mathrm{C}$. The solution was allowed to warm to room temperature and the $\mathrm{pH}$ adjusted to 1-3 with $2 \mathrm{M} \mathrm{HCl}$. The layers were separated and the aqueous extracted with DCM $(3 \times 25$ $\mathrm{ml})$. The total organic phase was dried $\left(\mathrm{MgSO}_{4}\right)$ and concentrated in vacuo to give a viscous yellow oil $(2.99 \mathrm{~g})$. Trituration with diethyl ether and filtration afforded a white solid $(0.95 \mathrm{~g}, 26 \%)$ : $\mathrm{mp} 78-80{ }^{\circ} \mathrm{C}$ [lit. $\left.{ }^{6} \mathrm{mp} 95-96{ }^{\circ} \mathrm{C}\right] ; \delta_{\mathrm{H}}\left(250 \mathrm{MHz}, \mathrm{CDCl}_{3}\right) 1.41\left(9 \mathrm{H}, \mathrm{s}, \mathrm{C}\left(\mathrm{CH}_{3}\right)_{3}\right), 1.93\left(2 \mathrm{H}, \mathrm{m}, \mathrm{CH}_{2}\right), 3.01(2 \mathrm{H}, \mathrm{t}, \mathrm{J} 7.2$, $\left.\mathrm{CH}_{2}\right), 3.21\left(2 \mathrm{H}, \mathrm{m}, \mathrm{CH}_{2}\right), 4.70(1 \mathrm{H}, \mathrm{br}-\mathrm{s}, \mathrm{NH}), 7.50(3 \mathrm{H}, \mathrm{m}, \mathrm{Ar}-\mathrm{H}), 7.94(2 \mathrm{H}, \mathrm{m}, \mathrm{Ar}-\mathrm{H})$; MS ES (+ve) found $\mathrm{m} / \mathrm{z} 264.0\left(\mathrm{MH}^{+}, 100 \%\right), 281.1\left(\mathrm{M}^{+}+\mathrm{H}_{2} \mathrm{O}, 66\right)$.

\section{Preparation of $(R)$-2-phenylpyrrolidine via intramolecular reductive amination}<smiles>CC(C)(C)OC(=O)NCCCC(=O)c1ccccc1</smiles>

To a solution of (5-oxo-5-phenyl-butyl)-carbamic acid tert-butyl ester 16 (0.20 g, $0.76 \mathrm{mmol})$ in DCM (5 $\mathrm{ml})$ at $0{ }^{\circ} \mathrm{C}$ was added TFA $(1 \mathrm{ml})$. The mixture was stirred at room temperature and the reaction progress monitored by TLC. Once complete, the reaction was basified with $4 \mathrm{M} \mathrm{NaOH}$ solution to $\mathrm{pH} 13-14$, the layers separated, and the aqueous phase extracted with DCM $(3 \times 10 \mathrm{ml})$. The total organic phase was dried $\left(\mathrm{MgSO}_{4}\right)$ and concentrated in vacuo to afford the crude 2-phenylpyrroline. To a suspension of whole cells $(1.0 \mathrm{~g})$ expressing the MAO-N-5 variant in $0.1 \mathrm{M}$ potassium phosphate buffer $(\mathrm{pH} 7)$ was added the crude 2-phenylpyrroline (14.5 mg, $10 \mathrm{mM}$ ) followed by ammonia borane (30.9 mg, $100 \mathrm{mM})$. The mixture was left shaking in an incubator $\left(37^{\circ} \mathrm{C}, 200 \mathrm{rpm}\right)$ overnight. A sample $(200 \mu \mathrm{l})$ was taken and placed on a hot-plate set to $100{ }^{\circ} \mathrm{C}$ for $5 \mathrm{~min}$ to denature the enzyme. The sample was then spun at maximum speed $(13,000 \mathrm{rpm})$ on a microcentrifuge and the supernatant decanted and analysed directly by CE (see General methods section for conditions): $\mathrm{t}_{\mathrm{R}} 24.8 \mathrm{~min}, 99 \% \mathrm{ee},\left[\mathrm{t}_{\mathrm{R}}(R)-2=24.8 \mathrm{~min} ; \mathrm{t}_{\mathrm{R}}(S)-2=25.1 \mathrm{~min}\right]$.

\section{References}

(1) Lewis, F. D.; Reddy, G. D.; Schneider, S.; Gahr, M. J. Am. Chem. Soc. 1991, 113, 3498.

(2) Perry, R. A.; Chen, S. C.; Menon, B. C.; Hanaya, K.; Chow, Y. L. Can. J. Chem. 1976, 54, 2385.

(3) Ebden, M. R.; Simpkins, N. S.; Fox, D. N. A. Tetrahedron 1998, 54, 12923.

(4) Malmberg, H.; Nilsson, M.; Ullenius, C. Acta Chem. Scand. B 1981, 35, 625.

(5) Pathak, T.; Thomas, N. F.; Akhtar, M.; Gani, D. Tetrahedron 1990, 46, 1733.

(6) Williams, G. D.; Pike, R. A.; Wade, C. E.; Wills, M. Org. Lett. 2003, 5, 4227. 